\title{
MODERNISASI PENDIDIKAN ISLAM DI MESIR
}

\author{
Tiy Kusmarrabbi Karo \\ Dosen Program Studi Pendidikan Bahasa Arab STAI As-Sunnah Deli Serdang \\ J1. Medan-Tg. Morawa, Km. 13 G. Darmo, Desa B. Sari, Kec. Tg. Morawa Kab. D. Serdang \\ Kusma70@yahoo.co.id
}

\begin{abstract}
Abstrak: Pembaharuan dalam Islam merupakan suatu keharusan yang terjadi dalam siklus kehidupan dengan tujuan memperbaiki segala persoalan hidup yang sangat dibutuhkan masyarakat pada saat itu sebagai akumulasi dari sebab akibat yang terjadi di masyarakat, tujuan akhir dari pembaharuan yang dilakukan oleh tokoh pembaharuan yaitu bagaimana Islam dapat menjawab segala persoalan yang terjadi di masyarakat dan tetap sesuai di segala zaman, serta ajaran Islam memberikan kontribusi yang positif dalam setiap perkembangan zaman. demikian pula apa yang terjadi di Mesir. Pembaharuan pendidikan Islam di Mesir lebih banyak berangkat dan digerakkan oleh para pemikir dan akademisi baik itu dari lulusan Al-Azhar sebagai tempat khazanah ilmu atau perguruan tinggi lainnya. Tulisan ini membahas tentang modernisasi pendidikan Islam di Mesir. Sementara itu pembahasannya meliputi; latar belakang pendidikan Islam Mesir pada Abad ke-18, strategi pembaruan pendidikan Islam, aspek-aspek modernisasi, tokohtokoh utamanya dan dampak yang dihasilkan.
\end{abstract}

Kata Kunci: Modernisasi, Pendidikan Islam

\section{Pendahuluan}

Pada awal abad ke 19 M kemajuan ilmu pengetahuan dan teknologi modern telah memasuki dunia Islam, kontak dengan dunia barat selanjutnya membawa ide-ide baru ke dunia Islam seperti rasionalisme, nasionalisme, demokrasi, dan sebagainya. Semua ini menimbulkan persoalan-persoalan baru, dan pemimpin-pemimpin Islam pun mulai memikirkan cara mengatasi persoalanpersoalan baru itu. Kaum terpelajar Islam mulai memusatkan perhatian pada perkembangan modern dalam Islam dan kata modernism-pun mulai pula diterjemahkan ke dalam bahasa-bahasa yang dipakai dalam Islam seperti at-tajdid dalam bahasa Arab dan pembaruan dalam bahasa Indonesia.

Sejarah telah mencatat bahwa pada masa klasik kontak yang terjadi antara umat Islam dengan dunia Barat menandakan akan kemajuan umat Islam saat itu. Akan tetapi hal itu berbalik di era modern ini, yang mana Barat berada dalam kegemilangan sedangkan Islam berada dalam kegelapan. Sehingga keadaan ini membuat berbagai pemikiran-pemikiran dan berbagai aliran pembaruan atau 
modernisasi dalam Islam muncul untuk mengembalikan kembali Islam pada kejayaannya seperti di masa klasik.

Pada era modern banyak tokoh pembaru yang muncul. Pada dasarnya mereka merasa tergugah untuk melakukan pembaruan. Mereka melihat keadaan umat Islam yang terjajah oleh bangsa Barat. Sehingga pemikiran yang mereka keluarkan bermaksud agar Islam bisa keluar dari penjajahan, bahkan bisa kembali jaya seperti halnya yang dialami di masa lampau. Kemajuan yang telah dicapai Barat, membuat mereka bersaing dalam menguasai daerah-daerah umat Islam. Mesir merupakan daerah yang strategis, sehingga tak heran jika Mesir menjadi salah satu negara Islam yang dijajah oleh Barat.

Tulisan ini membahas tentang modernisasi pendidikan Islam di Mesir. Sementara itu sub-sub judul pembahasannya meliputi; latar belakang pendidikan Islam Mesir pada Abad ke-18, strategi pembaruan pendidikan Islam, aspek-aspek modernisasi, tokoh-tokoh utamanya dan dampak yang dihasilkan.

\section{Latar Belakang Pendidikan Islam Mesir Abad ke-18}

Keberhasilan orang sipil Prancis membuka mata para pemikir Islam Mesir untuk melakukan perubahan, yaitu meninggalkan keterbelakangan menuju modernisasi di berbagai bidang, khususnya bidang pendidikan. Upaya pembaruan dipelopori oleh Muhammad Ali Pasya, kemudian diikuti oleh pemikir-pemikir lainnya. Pada masa itu, bidang pendidikan di Mesir sangat doktrinal, metode penguasaan ilmu menghafal di luar kepala tanpa ada pengkajian dan telaah pemahaman, membuat ajaran-ajaran Islam seperti dituangkan ke kepala murid dan mahasiswa sehingga mereka tinggal menerima apa adanya. ${ }^{1}$

Diskusi dan dialog menjadi barang langka dalam pengkajian keislaman. Selain itu, filsafat dan logika dianggap tabu sebagai matakuliah di perguruan tinggi dan madrasah. Sebagaimana dikatakan Muhammad Abduh, ia merasa jenuh dengan cara menerima ilmu dengan metode menghafal di luar kepala. Lebih jauh, Abduh menggambarkan bahwa metode pendidikan yang otoriter juga merupakan salah satu pendorong mandegnya kebebasan intelektual sehingga ia merasa tidak

\footnotetext{
${ }^{1}$ Abdul Kodir, Sejarah Pendidikan Islam dari Masa Rasulullah hingga Reformasi di Indonesia (Bandung: Pustaka Setia,2015 ), h. 114.
} 
begitu tertarik mendalami agama pada masa kecil karena kesalahan metode itu, yakni berupa cara menghafal pelajaran di luar kepala. ${ }^{2}$

Al- Azhar yang selama ini berkembang menjadi simbol kajian keilmuan juga terjangkit panyakit kejumudan, dengan hanya mengajarkan ilmu agama dan melarang segala bentuk kajian keilmuan yang berawal dari sisi rasionalitas merupakan barang baru yang sama sekali tidak berkembang di kalangan umat Islam Mesir. Tawaran -tawaran semacam itu akan menimbulkan reaksi yang keras, yang berkembang dari mereka yang tidak mau menggunakan rasionalitas dan pembahasan sistematis terhadap ajaran Islam.

Kehadiran Napoleon Bonaparte sangat berarti bagi timbulnya pola pendidikan dan pengajaran Barat yang sedikit demi sedikit mengubah persepsi dan pola pemikiran umat Islam. Hal ini melahirkan semangat pengkajian dan pembaruan dalam Islam. Napoleon Bonaparte memasuki Mesir sejak tahun 1798 M. Dalam tempo lebih kurang tiga minggu Napoleon telah dapat menaklukkan Mesir. Kedatangan Napoleon tidak hanya membawa pasukan, beliau juga membawa sejumlah ilmuan dalam berbagai bidang. Dalam rombongan terdapat 500 orang sipil dan 500 orang wanita, di antara kaum sipil itu terdapat 167 ahli dalam berbagai cabang ilmu pengetahuan. Ia juga membawa dua set alat percetakan huruf latin, Arab dan Yunani. Dengan demikian misinya ini tidak hanya untuk kepentingan militer tetapi juga untuk kepentingan ilmiah. ${ }^{3}$ Selain itu ia juga mendirikan di Mesir sebuah lembaga ilmiah yang diberi nama dengan Institut d 'Eqypt. Lembaga ini memiliki empat bidang kajian pokok, yaitu kajian ilmu pasti, ilmu alam, ekonomi politik, sastra, dan seni.

Di lembaga ini ditemukan beberapa perlengkapan-perlengkapan ilmiah yang belum dimiliki oleh masyarakat Mesir ketika itu, seperti mesin cetak, teleskop, mikroskop, dan alat-alat untuk percobaan kimia. ${ }^{4}$ Ini merupakan momentum baru bagi sejarah umat Islam, khususnya di Mesir yang menyebabkan bangkitnya kesadaran akan kelemahan dan keterbelakangan mereka.

\footnotetext{
${ }^{2}$ Ibid.

${ }^{3}$ Haidar Putra Daulay, Sejarah Pertumbuhan dan Pembaharuan Pendidikan Islam di Indonesia (Jakarta : Kencana, 2007 ), h.39.

${ }^{4}$ Ibid., 39-40.
} 
Pasca revolusi Prancis tahun 1798 M, Prancis menjadi negara yang besar. Napoleon melihat bahwa Mesir perlu diduduki oleh Perancis. Selain itu Mesir bisa dijadikan pasar baru untuk hasil perindustriannya. Napoleon ingin mengikuti jejak Alexander Macedonia yang pernah menguasai Eropa dan Asia. Ia dan pasukannya tiba di Mesir tepatnya di Alexandria tanggal 02 Juni 1798 dan keesokan harinya berhasil menguasai kota pelabuhan tersebut. Sembilan hari kemudian ia berhasil menguasai kota Rasyid. Pada tanggal 21 Juli ia berhasil mendekat ke Kairo. Napoleon mendapatkan perlawanan dari mamluk dan tanggal 22 Juli Mesir telah dapat dikuasai Napoleon.

Hasan Asari menyebutkan bahwa signifikansi terpenting dari penaklukan Napoleon adalah mengalirnya ide-ide baru yang populer sepanjang dan sesudah Revolusi Prancis ke Mesir. Pada skala yang lebih besar ini bisa disebut sebagai perkenalan modern yang lebih luas antara dunia Islam dan Barat. ${ }^{5}$ Pada tahap perkembangannya, pola pembaruan Islam kontemporer di Mesir lebih mengarah pada hal-hal berikut. Pertama, pembaruan sistem berpikir. Artinya, tata cara berpikir umat Islam harus meninggalkan pola pikir tradisional yang dogmatik. Kedua, upaya membangun semangat kolegial umat agar memperoleh kesempatan melakukan aktualisasi ajaran, terutama partisipasi aktif dalam percaturan politik, ekonomi, dan hukum di dunia. Hal ini disebabkan selama ini umat Islam secara aktif tidak mampu memberikan partisipasinya dalam percaturan dunia. ${ }^{6}$

Hal inilah yang membuka mata para pemikir-pemikir Islam untuk melakukan perubahan meninggalkan keterbelakangan menuju modernisasi di berbagai bidang khususnya bidang pendidikan. Upaya pembaharuan dipelopori oleh Muhammad Ali Pasya, kemudian diikuti oleh pemikir-pemikir lainnya.

\section{Strategi Pembaruan Pendidikan Islam}

Berikut ini adalah upaya dan strategi pembaruan pendidikan Islam yang dilakukan oleh sejumlah tokoh dan reformis di Mesir pada abad ke-19:

a. Mendirikan Kementerian Pendidikan dan Lembaga Pendidikan Sekolah

\footnotetext{
5 Hasan Asari, Modernisasi Islam: Tokoh, Gagasan dan Gerakan (Jakarta: Citapustaka Media, 2007), cet. ke-2, h. 55-56.

${ }^{6}$ Kodir, Sejarah Pendidikan Islam, h. 114-115.
} 
Para tokoh reformis generasi awal Mesir menyadari pentingnya arti pendidikan dan ilmu pengetahuan untuk kemajuan suatu negara. Sebagaimana di ketahui, Mesir ketika itu mempunyai sistem pendidikan tradisional yang berpusat pada kuttab, masjid, madrasah dan Jami’ al-Azhar. Madrasah merupakan satusatunya lembaga pendidikan umum yang terdapat di Mesir. Madrasah mementingkan pengajaran agama dan tidak memberikan pengetahuan umum, hal ini berbeda dengan sekolah sekolah modern yang sudah dikenal di Barat. Para tokoh reformis melihat bahwa pendidikan sangat perlu bagi kemajuan suatu negara. Tetapi bukan pendidikan yang bercorak tradisional yang ada di zaman itu.

Para tokoh reformis melihat madrasah-madrasah tradisional tidak dapat mengeluarkan tenaga-tenaga ahli dan terampil dan yang demikian itu sudah tidak sesuai dengan tuntan zaman maka dibentuklah Kementerian Pendidikan untuk pertama kalinya di Mesir, dan dibukalah sejumlah sekolah-sekolah modern yaitu sekolah militer pada tahun 1815, sekolah teknik pada tahun 1816, sekolah pertambangan tahun 1834 , sekolah pertanian di tahun 1836, sekolah kedokteran di tahun 1827, sekolah ketabiban di tahun 1836, dan sekolah penerjemahan pada tahun $1836 .^{7}$

b. Mengirim Pelajar-Pelajar Mesir untuk Belajar ke Barat

Pemerintah Mesir pada awal abad ke-18 mengirim pelajar-pelajar Mesir untuk belajar ke Eropa, tujuan utamanya adalah Italia, Perancis, Inggris dan Austria. Abd. Mukti menyebut pengiriman pelajar-pelajar Mesir ke Eropa itu dilaksanakan dalam tiga gelombang yaitu sebagai berikut:

Gelombang pertama, antara tahun 1809-1819, sebanyak 28 orang dikirim ke Italia yang tersebar di kota Leghore, Miglan, Florence dan Rome untuk mempelajari ilmu teknik, militer, industri kapal dan ilmu percetakan. Gelombang kedua, antara tahun 1826-1844, sebanyak 319 orang dikirim ke Paris Perancis. Dan gelombang ketiga, antara tahun 1844-1864, sebanyak 89 orang dikirim lagi ke Perancis.

${ }^{7}$ Harun Nasution, Islam Ditinjau dari Berbagai Aspeknya ( Jakarta: UI-Press, 1985), Jilid 2, cet. ke-5, h. 96. 
Dalam ketiga gelombang tersebut, pemerintah Mesir telah mengirimkan pelajar-pelajar Mesir ke Eropa sebanyak 436 orang yang tersebar di Italia, Perancis dan Inggris. ${ }^{8}$

c. Memperluas Akses Pendidikan

Para tokoh reformis awal di Mesir menginginkan perempuan memperoleh hak yang sama dengan laki-laki dalam memperoleh pendidikan. Setidaknya ada tiga alasan untuk itu: untuk menghasilkan perkawinan yang harmonis dan pemeliharaan anak yang baik; agar wanita dapat bekerja produktif sesuai dengan kapasitasnya; dan agar wanita tidak menghabiskan hidupnya dalam kungkungan harem. ${ }^{9}$ Pendidikan wanita itu perlu. Hal tersebut bukan hanya agar wanita dapat mengatur rumah tangga, melainkan juga agar mereka dapat memberikan pendidikan dasar bagi putra-putri mereka. Ide ini kemudian diteruskan oleh Thoha Husein (1899-1973) dan pada masanya (1954) wanita telah diizinkan kuliah di alAzhar.

Dengan demikian, gagasan memperjuangkan pendidikan wanita pada masa Islam modern menunjukkan adanya kesinambungan organik yang tidak terputus dari para pemikir sebelumnya sampai didirikannya akademi wanita di kompleks al-Azhar. $^{10}$

d. Menata Sistem dan Struktur Lembaga Pendidikan

Sejak masa kemunduruan Islam, sistem pendidikan yang berlaku di seluruh dunia Islam bercorak dualisme (artinya: pendidikan madrasah yang menolak pelajaran-pelajaran umum dan pendidikan modern berbasis Barat yang tidak mengajarkan ilmu agama). Dengan melakukan lintas disiplin ilmu antar kurikulum madrasah dan sekolah, maka jurang pemisah antara golongan ulama dan ilmuwan modern akan dapat diperkecil. Pembaharuan pendidikan ini dilakukan dengan menata kembali struktur pendidikan di Al-Azhar, kemudian di sejumlah institusi pendidikan lain yang berada di Thanta, Dassuq, Dimyat dan Iskandariyah. $^{11}$

\footnotetext{
${ }^{8}$ Abd Mukti, Pembaharuan Lembaga Pendidikan di Mesir (Bandung: Citapustaka Media Perintis, 2008), h. 99-101.

${ }^{9}$ Asari, Modernisasi Islam, h. 60-61.

${ }^{10}$ journal.uinsgd.ac.id/index.php/jpi/article/download/549/pdf, diakses 26 Oktober 2017.

${ }^{11}$ Ibid.
} 
Tidak hanya itu, pada saat itu telah dibagi pula struktur pendidikan menjadi tiga tingkatan, yaitu tingkat pendidikan permulaan, tingkat pendidikan menengah, dan tingkat pendidikan tinggi sebagai pendidikan akhir. ${ }^{12}$

e. Mengitegrasikan Kurikulum Pendidikan

Generasi awal para pembaru pendidikan Islam di Mesir telah merumuskan tiga macam kurikulum yaitu: Pertama, Kurikulum Al-Azhar. Kurikulum perguruan tinggi Al-Azhar disesuaikannya dengan kebutuhan masyarakat pada masa itu. Dalam hal ini dimasukkanlah ilmu filsafat, logika dan ilmu pengetahuan modern ke dalam kurikulum Al-Azhar. Upaya ini dilakukan agar out-putnya dapat menjadi ulama modern. Kedua, Kurikulum Sekolah Dasar. Pembentukan jiwa agama hendaknya sudah dimulai semenjak masa kanak-kanak. Oleh karena itu, matapelajaran agama hendaknya dijadikan sebagai inti semua mata pelajaran. Pandangan ini mengacu pada anggapan bahwa ajaran agama Islam merupakan dasar pembentukan jiwa dan pribadi muslim. Dengan memiliki jiwa keperibadian muslim, rakyat Mesir akan memiliki jiwa kebersamaan dan nasionalisme untuk dapat mengembangkan sikap hidup yang baik, sekaligus dapat meraih kemajuan. Ketiga, Kurikulum Sekolah Menengah dan Sekolah Kejuruaan. Didirikannya sekolah menengah pemerintahan untuk menghasilkan tenaga ahli dalam berbagai lapangan administrasi, militer, kesehatan, perindustrian dan sebagainya. Melalui lembaga pendidikan ini, dipandang perlu untuk memasukkan beberapa materi, khususnya pendidikan agama, sejarah Islam, dan kebudayaan Islam. Dengan tujuan agar lahir tenaga-tenaga ahli yang berwawasan keagamaan.

f. Menciptakan Inovasi Baru dalam Metode Pendidikan

Strategi pembaruan di bidang metode pendidikan yaitu dengan menekankan perkembangan metode pendidikan yang sesuai dengan perkembangan zaman. Sebut saja sebagai contoh Muhammad Abduh salah satu tokoh sentral pembaruan pendidikan Islam di Mesir mengubah cara memperoleh ilmu dengan metode hafalan, rasional, dan pemahaman (insight). Di samping menghafal, siswa juga harus memahami materi yang dihafalnya. Selain itu, Abduh juga menghidupkan kembali metode munazharah dalam memahami pengetahuan dan menjauhkan metode taklid buta terhadap para ulama. Ia pun mengembangkan

${ }^{12}$ Ramayulis dan Samsul Nizar, Ensiklopedi Tokoh Pendidikan Islam: Mengenal Tokoh Pendidikan di Dunia Islam dan Indonesia (Ciputat: Ciputat Press Group, 2005), h. 42. 
kebebasan ilmiah di kalangan mahasiswa Al-Azhar. Ia menjadikan bahasa Arab yang selama ini hanya merupakan ilmu yang tidak berkembang menjadi ilmu yang berkembang dan dapat dipergunakan untuk menerjemahkan teks-teks pengetahuan modern ke dalam bahasa Arab. ${ }^{13}$

\section{Aspek-Aspek Modernisasi}

Modernisasi pendidikan Islam di Mesir tidaklah terjadi dalam kevakuman kebudayaan dan peradaban masyarakatnya. Sebagaimana telah dijelaskan sebelumnya bahwa, kontak yang terjadi antara masyarakat Mesir dan peradaban Barat Modern selama pendudukan Napoleon telah menyadarkan para reformis Mesir akan kemunduran negeri itu. Ketika itu mereka yakin dan percaya bahwa, untuk membangun negeri Mesir dalam ketertinggalannya dari Barat khususnya dalam bidang pendidikan maka mereka melakukan sejumlah pembaharuan dalam beberapa aspek di dunia pendidikan Islam, di antaranya:

\section{Memodernisasi Lembaga Pendidikan Islam}

Untuk membangun negeri Mesir dalam berbagai bidang sangat diperlukan ilmu-ilmu modern dan sains dan lain sebagainya yang dikenal di Barat. Untuk itulah para tokoh reformis memodernisasikan lembaga pendidikan Islam dengan mendirikan sekolah-sekolah dan memasukkan ilmu-ilmu modern dan sains ke dalam kurikulumnya. Sekolah-sekolah inilah yang kemudian dikenal sebagai sekolah modern di Mesir pada khususnya dan dunia Islam pada umumnya.

Saat itu Mesir masih mempunyai sistem pendidikan tradisional yaitu kuttab, masjid, madrasah dan jami' al-Azhar. Sementara itu, jika memasukkan kurikulum modern ke dalam lembaga pendidikan tradisional terebut maka sangat sulit, oleh karena itulah para tokoh reformis mengambil jalan alternatif dengan cara mendirikan sekolah modern disamping madrasah-madrasah tradisional yang telah ada pada masa itu tetap berjalan.

\section{Memodernisasi Kurikulum Pendidikan Islam}

Sekolah-sekolah modern saat itu telah mempunyai jenjang-jenjang pendidikan yang terdiri atas tingkat rendah, menengah dan tingkat tinggi. Ketiga tingkat tersebut, masing-masing mempunyai kurikulumnya, dan kurikulumnya

\footnotetext{
${ }^{13}$ Kodir, Sejarah Pendidikan Islam, h. 124-125.
} 
telah diintegrasikan antara matapelajaran agama dengan mata pelajaran umum, gambarannya sebagai berikut:

a. Kurikulum tingkat rendah, terdiri dari mata pelajaran pokok yaitu membaca dan menulis, juga diajarkan geografi dan ilmu berhitung. Pelajaran agama juga dijadikan sebagai salah satu mata pelajaran. Selain itu bahasa Arab diajarkan juga dan sekaligus berfungsi sebagai bahasa pengantar.

b. Kurikulum tingkat menengah, mata pelajaran pokok terdiri dari ilmu berhitung, matematika dan bahasa Italia. Bahasa Arab dan bahasa Turki dijadikan mata pelajaran dan sejak tahun 1820 mulai diajarkan bahasa Perancis. Hukum Islam juga diajarkan pada tingkat ini. Ilmu lainnya dijadikan sebagai mata pelajaran pokok pada setiap sekolah menengah sesuai dengan jurusannya masing-masing.

c. Kurikulum tingkat tinggi, kurikulumnya terdiri dari mata pelajaran matematika dan ilmu-ilmu lainnya sesuai dengan jurusannya masingmasing. Bahasa Arab, Turki, Perancis dan Italia juga diajarkan demikian juga pengetahuan agama dijadikan salah satu mata pelajaran. ${ }^{14}$

\section{Tokoh-Tokoh Utama}

Upaya pembaharuan Islam di Mesir dipelopori oleh sejumlah tokoh antara lain Muhammad Ali Pasya, Rifa'ah Badawi at-Tahtawi, Jamaluddin al-Afghani, Muhammad Abduh, Muhammad Rasyid Ridha dan lain-lain.

\section{Muhammad Ali Pasya}

Muhammad Ali Pasya adalah seorang tokoh pembaru di Mesir yang berasal dari keturunan Turki lahir di Kawalla, Yunani, pada tahun 1765 dan meninggal di Mesir pada tahun 1849. Orang tuanya bekerja sebagai penjual rokok. Ia berasal dari keluarga yang kurang mampu. Karena keterbatasan ekonomi ia tidak memperoleh kesempatan sekolah sehingga ia tidak pandai membaca dan menulis. ${ }^{15}$ Sekalipun demikian, ia adalah seorang anak yang cerdas dan pemberani. Hal itu tampak dalam kariernya, baik dalam bidang militer maupun sipil yang selalu sukses.

\footnotetext{
${ }^{14}$ Mukti, Pembaharuan Lembaga Pendidikan, h. 93-95.

${ }^{15}$ Kodir, Sejarah Pendidikan Islam, h. 115.
} 
Setelah dewasa, Muhammad Ali bekerja sebagai pemungut pajak. Karena rajin bekerja, ia disukai gubernur Usmani dan akhirnya menjadi menantu gubernur. Setelah menikah, ia diterima menjadi anggota meliter. Keberanian dan kecakapan menjalankan tugas menyebabkan ia diangkat menjadi perwira. Pada saat penyerangan Napoleon ke Mesir, Sultan Turki mengirimkan bantuan tentara ke Mesir dan Muhammad Ali Pasya termasuk di dalamnya. Bahkan, ia ikut bertempur melawan Napoleon pada tahun $1801 .^{16}$

Setelah mendapat kepercayaan rakyat dan pemerintah pusat Turki, Muhammad Ali menumpas musuh-musuhnya, terutama golongan Mamluk yang masih berkuasa di daerah-daerah. Dengan demikian, ia menjadi penguasa tunggal di Mesir. Ali Pasya juga disebut sebagai orang pertama yang meletakkan landasan kebangkitan modern Mesir ${ }^{17}$ bahkan ia disebut sebagai bapak pembangunan modern (The Founder of Modern Egypt). Pembaharuan yang dilakukan oleh Muhammad Ali yaitu:

a. Membangun kekuatan militer;

b. Pendidikan;

c. Ekonomi;

d. Bidang pemerintahan;

e. Dan Politik luar negeri.

Perhatiannya di bidang pendidikan mendapat prioritas utama. Sekalipun tidak pandai membaca dan menulis, Muhammad Ali memahami pentingnya arti pendidikan dan ilmu pengetahuan untuk kemajuan suatu negara. Hal ini terbukti dengan dibentuknya Kementerian Pendidikan untuk pertama kalinya di Mesir, dibukanya sekolah militer pada tahun 1815, sekolah teknik pada tahun 1816 , sekolah pertambangan tahun 1834, sekolah pertanian di tahun 1836, sekolah kedokteran di tahun 1827, sekolah ketabiban di tahun 1836, dan sekolah penerjemahan (1836). ${ }^{18}$

Selain mendirikan sekolah, ia juga mengirimkan pelajar ke Eropa, terutama ke Paris sekitar 300 orang. Setelah itu, mereka kembali ke Mesir mereka diberi tugas menerjemahkan buku-buku Eropa ke dalam bahasa Arab dan

\footnotetext{
${ }^{16} \mathrm{Ibid}$.

${ }^{17}$ Harun Nasution, Islam Ditinjau, h. 96.

${ }^{18}$ Ibid.
} 
mengajar di sekolah-sekolah yang ada di Mesir. ${ }^{19}$ Muhammad Ali mendirikan penerbitan untuk menyebar luaskan ilmu-ilmu baru ini. Meski pada mulanya ia bermaksud membatasi skop kegiatan para mahasiswa ini hanya pada skil-skil yang akan mendukung kekuasaannya, dalam kenyataannya tidaklah demikian. Para mahasiswa yang dikirim ke Eropa ini pada gilirannya membawa kembali ideide baru. $^{20}$

Berikut ini akan dijelaskan sejumlah pembaruan dan inovasi yang dilakukan Muhammad Ali Pasya dalam bidang pendidikan di Mesir:

a. Mendirikan Sekolah Modern

Muhammad Ali Pasya, pemimpin Mesir ketika itu yakin dan percaya bahwa untuk membangun negeri Mesir dalam berbagai bidang sangat diperlukan ilmu-ilmu modern dan sains dan lain sebagainya yang dikenal di Barat. Untuk itulah ia memodernisasikan lembaga pendidikan Islam dengan mendirikan sekolah-sekolah dan memasukkan ilmu-ilmu modern dan sains ke dalam kurikulumnya. Sekolah-sekolah inilah yang kemudian dikenal sebagai sekolah modern di Mesir pada khususnya dan dunia Islam pada umumnya.

Saat itu Mesir masih mempunyai sistem pendidikan tradisional yaitu kuttab, masjid, madrasah dan jami' al-Azhar. Sementara itu ia melihat jika ia memasukkan kurikulum modern ke dalam lembaga pendidikan tradisional terebut maka sangat sulit, oleh karena itulah ia mengambil jalan alternatif dengan cara mendirikan sekolah modern sidamping madrasah-madrasah tradisional yang telah ada pada masa itu tetap berjalan.

Adapun nama-nama sekolah modern yang didirikan Muhammad Ali Pasya: $^{21}$

\begin{tabular}{|l|l|l|l|l|}
\hline No & \multicolumn{1}{|c|}{ Nama Sekolah } & Tahun Berdiri & Tempat & Tingkatan \\
\hline 1 & Sekolah Meliter & 1815 & Kairo & Menengah \\
\hline 2 & Sekolah Teknik & 1816 & Kairo & Menengah \\
\hline 3 & Sekolah Kedokteran & 1827 & Kairo & Menengah \\
\hline 4 & Sekolah Apoteker & 1829 & Kairo & Menengah \\
\hline
\end{tabular}

\footnotetext{
${ }^{19}$ Kodir, Sejarah Pendidikan Islam, h. 117.

${ }^{20}$ Asari, Modernisasi Islam, h. 58.

${ }^{21}$ Mukti, Pembaharuan Lembaga Pendidikan, h. 77-78.
} 


\begin{tabular}{|l|l|l|l|l|}
\hline 5 & Sekolah Pertambangan & 1834 & Kairo & Menengah \\
\hline 6 & Sekolah Pertanian & 1836 & Kairo & Menengah \\
\hline 7 & Sekolah Penerjemah & 1836 & Kairo & Menengah \\
\hline 8 & Sekolah Dasar & 1833 & Kairo & Dasar \\
\hline 9 & $\begin{array}{l}\text { Sekolah Menengah } \\
\text { Umum }\end{array}$ & 1825 & $\begin{array}{l}\text { Kasr al- } \\
\text { 'Ayni }\end{array}$ & Menengah \\
\hline 10 & Politeknik & 1820 & Kairo & Tinggi \\
\hline 11 & Sekolah Accounting & 1826 & Kairo & Menengah \\
\hline 12 & Sekolah Sipil & 1829 & Kairo & Menengah \\
\hline 13 & Sekolah Irigasi & 1831 & Kairo & Menengah \\
\hline 14 & Sekolah Industri & 1831 & Kairo & Menengah \\
\hline 15 & Sekolah Administrasi & 1834 & Kairo & Menengah \\
\hline 16 & Sekolah Pertanian & 1834 & Kairo & Menengah \\
\hline 17 & Sekolah Perwira A. Laut & - & Alexandria & Menengah \\
\hline 18 & Sekolah Industri Bahari & - & Alexandria & Tinggi \\
\hline 19 & $\begin{array}{l}\text { Sekolah Tinggi } \\
\text { Kedokteran }\end{array}$ & 1823 & Kairo & Tinggi \\
\hline
\end{tabular}

Jika kita perhatikan sistem pendidikannya, maka semua sekolah-sekolah yang didirikan oleh Muhammad Ali Pasya adalah memiliki ciri sekolah modern. Maka pada pemerintahannya ada dua jenis pendidikan yang menurutnya keduanya mimiliki fungsi dan peran berbeda dalam menunjang kemajuan dan perkembangan Mesir saat itu. Sekolah tradisional adalah sekolah yang hanya mempelajari ilmu agama yang alumninya tidak menguasai ilmu umum. Sedangkan sekolah modern akan mengeluarkan alumni yang menguasai ilmu umum yang dapat menstimulus perkembangan pembaharuan Mesir. ${ }^{22}$

Bila dilihat pada jenisnya, maka hampir semua sekolah menengah modern tersebut di atas merupakan sekolah kejuruan yang meliputi kejuruan meliter, teknik, pertanian, ekonomi, kedokteran dan administrasi yang bertujuan untuk mendidik tenaga-tenaga ahli Mesir dalam bidangnya masing-masing yang pada gilirannya nanti akan mengeluarkan alumni-alumni yang dapat menggantikan tenaga-tenaga kerja asing yang dipakai selama ini. Hal itu berarti pendidikan di

\footnotetext{
${ }^{22}$ Ibid., h. 78 .
} 
sekolah ini sudah mementingkan kepada kebutuhan masyarakat dan masa depan pelajar-pelajar sendiri.

Karena dalam penyelenggaraannya, sekolah-sekolah modern tersebut masih belum sempurna, di sana-sini masih terdapat kekurangan, terutama dalam hal penyebarannya, jumlahnya yang belum berimbang dengan jumlah murid dan jenjang pendidikannya, maka pada tahun 1250/1834 dibentuklah sebuah komisi pendidikan. komisi ini bertugas menyusun kembali teknis pelaksanaan pendidikan dengan mengusulkan antara lain: ${ }^{23}$

1) Penambahan pembangunan Sekolah Dasar sebanyak lima puluh buah lagi di Kairo dan propinsi-propinsi.

2) Penambahan Sekolah Menengah Umum, semacam SMA di Indonesia, yang berfungsi menghubungkan antara Sekolah Dasar dengan Sekolah Tinggi, di Iskandariah.

3) Menetapkan jenjang sekolah menjadi tingkat dasar, menengah dan tingkat tinggi.

Tetapi sayangnya laporan komisi ini tidak sampai ke tangan Muhammad Ali Pasya, sehingga tidak banyak yang dapat dilakukan olehnya dalam memperbaiki sistem pendidikan sampai ke akhir masa pemerintahannya. Barulah setelah reorganisasi pendidikan yang dilakukan oleh Khedewi Ismail, sistem pendidikan baru ini memperlihatkan pengaruhnya yang besar. Kemudian dilanjutkan oleh Sultan Ahmad Fuad I dan Raja Faruq. ${ }^{24}$

Tampaknya, Muhammad Ali Pasya telah mengadakan pembaharuan yang besar dalam lembaga pendidikan dengan mendirikan sejumlah sekolah-sekolah modern sebagaimana yang telah diuraikan di atas pada permulaan abad kedelapan belas.

b. Merevisi Kurikulum Pendidikan

Dengan dibukanya sekolah dasar sejak tahun 1833 danusaha ini lebih ditingkatkan lagi pada tahun-tahun berikutnya, bukan hanya di ibu kota saja tetapi juga di propinsi-propinsi, sehingga pada tahun 1836, jumlahnya sudah mencapai 50 buah, maka sekolah-sekolah modern yang didirikan oleh Muhammad Ali Pasya sampai saat itu sudah mempunyai jenjang-jenjang pendidikan yang terdiri

\footnotetext{
${ }^{23}$ Ibid., h. 80 .

${ }^{24}$ Ibid., h. 81 .
} 
atas tingkat rendah, menengah dan tingkat tinggi. Ketiga tingkat tersebut, masingmasing mempunyai kurikulumnya, yaitu sebagai berikut:

Pertama, tingkat rendah, tujuannya untuk mempersiapkan calon-calon siswa sekolah menengah. Kurikulumnya terdiri dari mata pelajaran pokok yaitu membaca dan menulis, juga diajarkan geografi dan ilmu berhitung. Pelajaran agama juga dijadikan sebagai salah satu mata pelajaran. Selain itu bahasa Arab diajarkan juga dan sekaligus berfungsi sebagai bahasa pengantar.

Kedua, kurikulum tingkat menengah, mata pelajaran pokok terdiri dari ilmu berhitung, matematika dan bahasa Italia. Bahasa Arab dan bahasa Turki dijadikan mata pelajaran dan sejak tahun 1820 mulai diajarkan bahasa Perancis. Hukum Islam juga diajarkan pada tingkat ini. Ilmu lainnya dijadikan sebagai mata pelajaran pokok pada setiap sekolah menengah sesuai dengan jurusannya masingmasing.

Ketiga, tingkat tinggi, kurikulumnya terdiri dari mata pelajaran matematika dan ilmu-ilmu lainnya sesuai dengan jurusannya masing-masing. Bahasa Arab, Turki, Perancis dan Italia juga diajarkan demikian juga pengetahuan agama dijadikan salah satu mata pelajaran. ${ }^{25}$

c. Menerjemahkan Buku-Buku Pelajaran Umum dari Bahasa Eropa ke dalam Bahasa Arab

Buku pelajaran merupakan salah satu soal penting yang dihadapi dalam pelaksanaan pendidikan dan pengajaran pada sekolah-sekolah yang dibangun oleh Muhammad Ali Pasya ketika itu. Kalau buku-buku pelajaran agama tidak mengalami kesulitan yang berarti karena dapat diperoleh dengan mudah di Mesir sendiri, tidak demikian halnya dengan buku-buku pelajaran umum yang tidak dijumpai di Mesir pada waktu itu, karena di dalam sistem pendidikan tradisional, kelihatannya, belum begitu membutuhkan kepada buku-buku pelajaran yang berisikan ilmu-ilmu modern.

Maka salah satu usaha untuk mengatasi persoalan buku ialah dengan cara menerjemahkan buku-buku yang dipakai oleh sekolah-sekolah Eropa, terutama sekolah Italia dan Perancis ke dalam bahasa Arab. Usaha ini dilaksanakan oleh penerjemah-penerjemah yang pandai berbahasa asing yang bekerja di Dewan

\footnotetext{
${ }^{25}$ Ibid., h. 93-95.
} 
Muhammad Ali Pasya, pegawai-pegawai departemen dan mahasiswa-mahasiswa yang sedang belajar di Eropa. ${ }^{26}$

Di antara buku-buku yang diterjemahkan ialah buku-buku mengenai filsafat, biografi, logika, geografi, travels (kunjungan-kunjungan ke negara-negara asing), politik dan antropologi.

Kegiatan penerjemahan ini mengalami kemajuan pesat setelah didirikannya Sekolah Bahasa oleh al-Thanthawai dan dia sendiri menjadi direkturnya selama beberapa tahun, di sekolah ini pelajar-pelajar mempelajari bahasa Perancis selama lima atau enam tahun di samping matematika dan hukum Islam. Sekolah ini ketika itu menjadi pusat penerjemahan penting, bukan hanya menerjemahkan buku-buku Eropa ke dalam bahasa Arab tetapi juga mempersiapkan buku-buku pelajaran (texbooks) ke dalam jumlah yang banyak. ${ }^{27}$

Sepintas pembaharuan yang dilakukan oleh Muhammad Ali hanya bersifat keduniaan saja, namun dengan terangkatnya kehidupan dunia ummat Islam sekaligus terangkat pula derajat keagamaannya. Pembaharuan yang dilaksanakan oleh Muhammad Ali merupakan landasan pemikiran dan pembaharuan selanjutnya. Pembaharuan Muhammad Ali dilanjutkan oleh Tahtawi, Jalaludin AlAfghani, Muhammad Abduh, Rasyid Ridha dan murid-murid Muhammad Abduh lainnya.

\section{Rifa'ah Badawi Rafi' al-Tahtawi}

Rifa'ah Badawi al-Tahtawi lahir di Tahta tahun 1801. Nama kecilnya adalah Rafi'ah ibn al-Mahrun as-Sayyid Badawi Rafi' al-Tahtawi al-Huseini. Ia wafat pada tahun 1873 di Kairo. Sejak kecil ia sudah dipaksa belajar dengan bantuan keluarga dari ibunya. Pada usia 16 tahun ia belajar di al-Azhar. Kemudian ia melanjutkan studi di Perancis. Dalam perjalanan ke Paris ia belajar bahasa Perancis dan dalam waktu singkat dapat menguasainya dengan baik. Dengan kemampuan tersebut, ia membaca dan mempelajari buku-buku sejarah, filsafat Yunani, ilmu hitung, logika, bahkan pemikiran para pemikir bangsa Perancis abad ke-19, seperti Voltaire, Condillac, Rousseau, dan Montesquieu. ${ }^{28}$ Selama di Paris

\footnotetext{
${ }^{26}$ Ibid., h. 96.

${ }^{27}$ Ibid., h. 97-98.

${ }^{28}$ Ramayulis dan Nizar, Ensiklopedi Tokoh Pendidikan Islam, h. 37.
} 
ia telah menerjemahkan 12 buku penting dalam berbagai bidang, seperti sejarah, pertambangan, akhlak dan adat istiadat, ilmu bumi, teknik, hak-hak manusia, kesehatan jasmani, dan sebagainya. ${ }^{29}$

Sekembalinya ke Mesir, ia diberi jabatan sebagai guru bahasa Perancis dan berbagai jabatan kepala sekolah, serta pimpinan Badan Penerjemah Undangundang Perancis. Latar belakang dan pengalaman tersebut turut membentuk wawasan pendidikan Tahtawi. Ide tentang kebebasan yang ia peroleh dari pengalaman di Perancis ia susun dalam buku sosial politik yang berjudul Tarikh al-Ibriz ila Talkhis Baris. ${ }^{30}$

Al-Tahtawi juga pernah menjadi pimpinan surat kabar al-Waqa'i alMishriyah. Selain memuat berita-berita resmi ia juga memuat pengetahuan tentang kemajuan Barat. Di salah satu karangannya ia menerangkan tentang teoriteori demokrasi. Pokok-pokok pemikiran al-Tahtawi dalam mengadakan pembaharuan diantaranya :

a. Ajaran Islam bukan hanya mementingkan soal akhirat tetapi juga soal hidup di dunia. Umat Islam harus mementingkan hidup duniawinya.

b. Kekuasaan absolut raja harus dibatasi oleh syari'at, dan raja harus bermusyawarah dengan ulama dan kaum terpelajar seperti dokter, ekonom dan lain-lain.

c. Syari'at harus disesuaikan dengan perkembangan modern.

d. Kaum ulama harus belajar falsafat dan ilmu pengetahuan modern agar sesuai dengan syariat dan kebutuhan zaman modern.

e. Pendidikan harus bersifat universal untuk semua golongan. Wanita harus memperoleh pendidikan yang sama dengan pria.

f. Umat Islam harus bersifat dinamis dan meninggalkan sifat statis. ${ }^{31}$

Di antara pendapat baru yang dikemukakannya adalah ide pendidikan yang universal. Sasaran pendidikannya terutama ditujukan kepada pemberian kesempatan yang sama antara laki-laki dan perempuan di tengah masyarakat. Menurutnya, perbaikan pendidikan hendaknya dimulai dengan memberikan

${ }^{29}$ Nasution, Pembaharuan Dalam, h. 43. Lihat juga John J. Donohue dan John L. Esposito (ed.), Islam dan Pembaharuan: Ensiklopedi Masalah-masalah, terj. Machnun Husein (Jakarta: Rajawali Press, 1984), h. 7.

${ }^{30}$ Ramayulis dan Nizar, Ensiklopedi Tokoh Pendidikan Islam, h. 37.

${ }^{31}$ Nasution, Islam Ditinjau, h. 97. 
kesempatan belajar yang sama antara pria dan wanita, sebab wanita itu memegang posisi yang menentukan dalam pendidikan. Wanita yang terdidik akan menjadi isteri dan ibu rumah tangga yang berhasil. Mereka yang diharapkan melahirkan putra-putri yang cerdas. Tahtawi membagi struktur pendidikan menjadi tiga tingkatan. Pertama, tingkat pendidikan dasar. Diberikan secara umum kepada anak-anak dengan materi pelajaran dasar tulis baca, berhitung, al-Qur'an, agama, dan matematika. Kedua, tingkat pendidikan menengah. Materinya berkisar pada ilmu sastra, ilmu alam, biologi, bahasa asing, dan ilmu-ilmu keterampilan. Ketiga, pendidikan tinggi. Tugas utamanya adalah menyiapkan tenaga ahli dalam berbagai disiplin ilmu. ${ }^{32}$

Meskipun pemikiran al-Tahtawi belum dapat diwujudkan seluruhnya pada masa itu, ia telah membuat suatu terobosan yang akan diikuti oleh para modernis sesudahnya.

\section{Muhammad Abduh}

Muhammad Abduh lahir di suatu desa di propinsi Gharbiyyah Mesir pada tahun $1265 \mathrm{H} / 1849 \mathrm{M}$, namun adapula yang mengatakan ia lahir sebelum tahun itu. Ayahnya bernama Abdullah Hasan Khairullah berasal dari Turki yang lama Tinggal di Mesir. Muhammad Abduh adalah seorang yang cerdas, akan tetapi pada awalnya ia tidak terlalu bersemangat dalam menuntut ilmu. Kemudian ia belajar bersama Syekh Darwisy, bersamanya Abduh menjadi semangat membaca, karena Syekh Darwisy sering mengajak Abduh untuk membaca bersama. Setelah selesai belajar bersama Darwisy, Abduh melanjutkan studinya di al-Azar Mesir. Dalam masa studinya itu, Abduh bertemu dengan Jamaluddin al-Afghani, ia pun berguru kepadanya, ia juga menjadi murid yang paling setia.

Munculnya pemikiran Muhammad Abduh tentang pendidikan di latar belakangi oleh kondisi sosial dan pemahaman keagamaan umat Islam Mesir waktu itu. Kondisi tersebut ditandai dengan pemikiran yang statis dan jumud, serta sistem pendidikan yang bersifat dualistik. Kondisi yang sesungguhnya tidak menguntungkan bagi umat Islam. Persoalan tersebut muncul karena ketidaktahuan umat Islam pada universalitas ajaran Islam yang sesungguhnya. ${ }^{33}$

\footnotetext{
${ }^{32}$ Ramayulis dan Nizar, Ensiklopedi Tokoh Pendidikan Islam, h. 42.

${ }^{33}$ Ibid., h. 24-25.
} 
Pada awalnya upaya Muhammad Abduh yang mencoba bersikap akomodatif terhadap ilmu-ilmu umum Barat mendapat tantangan yang cukup berat, terutama dari ulama al-Azhar yang masih berpikiran tradisional dan statis, serta masyarakat awam yang dapat masih dipengaruhi oleh ulama tradisional. Untuk itu, tidak heran jika akhirnya Muhammad Abduh di hujat dan pada tahun 1905 harus rela tersigkir dari lingkungan Universitas al Azhar. Akibat dari sikap yang kurang bersahabat terhadap ide-ide pembaruan yang coba ditawarkan oleh Muhammad Abduh, menyebabkan ide-ide pembaruannya yang briliyan di bidang pendidikan tak bisa terlaksana secara konkrit. Hal-hal yang dilakukan oleh Muhammad Abduh dalam mengadakan pemikiran pembaharuan di antaranya :

a. Mendirikan majalah ar-urwatul wutsqa bersama rekannya Jamaluddin alAfghani.

b. Mengajak umat kembali kepada ajaran Islam sejati.

c. Ajaran kemasyarakatan dalam Islam dapat disesuaikan dengan zaman.

d. Taklid dihapuskan dan ijtihad dihidupkan ulama.

e. Islam katanya rasional, menghendaki akal, waktu, tidak bertentangan dengan akal, bila lahirnya ayat tidak bertentangan dengan pendapat akal maka harus dicarikan interpretasinya hingga sesuai dengan pendapat akal.

f. Islam tidak bertentangan dengan ilmu, Islam maju karena ilmu.

Menurut Abduh, pendidikan merupakan lembaga yang paling strategis untuk mengadakan pembaharuan-pembaharuan sosial secara sistematis. Gagasannya yang paling mendasar dalam sistem pendidikan adalah bahwa ia sangat menentang sistem dualisme. Menurutnya, dalam lembaga-lembaga pendidikan umum harus diajarkan agama. Sebaliknya, dalam lembaga-lembaga pendidikan agama harus diajarkan ilmu pengetahuan modern. Usaha yang dilakukan oleh Abduh dalam mewujudkan gagasan pembaharuannya adalah melalui Universitas al-Azhar. Menurutnya, seluruh kurikulum pendidikan disesuaikan dengan kebutuhan saat itu. Ilmu-ilmu filsafat dan logika yang sebelumnya tidak diajarkan, dihidupkan kembali. ${ }^{34}$ Demikian juga dengan ilmuilmu umum perlu diajarkan di Universitas al-Azhar. Dengan memasukkan ilmu pengetahuan modern ke lembaga-lembaga pendidikan agama dan sebaliknya,

\footnotetext{
${ }^{34}$ Kodir, Sejarah Pendidikan Islam, h. 123.
} 
dimaksudkan untuk memperkecil jurang pemisah antara golongan ulama dan ahli modern, dan diharapkan kedua golongan ini bersatu dalam menyelesaikan persoalan-persoalan yang muncul di zaman modern.

\section{Rasyid Ridha}

Rasyid Ridha adalah murid Muhammad Abduh yang terdekat. Ia lahir di Al-Qalamun, sebuah desa di Lebanon yang letaknya tidak jauh dari Kota Syiria tahun $1282 \mathrm{H}$ atau $1865 \mathrm{M}$. Ia termasuk keturunan Husein bin Ali bin Abu Thalib ra. yang memiliki darah keturunan Rasulullah saw., yaitu cucu beliau. Oleh karena itu, ia memakai gelar As-Sayyid di depan namanya. ${ }^{35}$ Rasyid Ridha belajar di sekolah Pemerintah Ustmani dan di sekolah Syeikh Husein Jisr, keduanya di Tripoli, Lebanon. ${ }^{36}$ keluarganya sangat dijaga oleh budi pekerti yang mulia dan terkenal sebagai dai-dai Islam, menjadi suri tauladan bagi manusia dalam hal ibadah, ilmu, keutamaan dan menjaga diri serta keluhuran di mata Allah. Kemampuannya dalam memahami segala pandangannya yang menonjol inilah yang kemudian membawanya pada pemikiran-pemikiran Islam cemerlang di majalah terbitan al-Manar. Rasyid Ridha melanjutkan studinya hingga memperoleh Ijazah Alamiyah.

Rasyid Ridha mulai mencoba menjalankan ide-ide pembaruan itu ketika masih berada di Syiria, tetapi usaha-usahanya mendapat tantangan dari pihak Kerajaan Usmani. Ia merasa terikat dan tidak bebas. Oleh Karena itu ia memutuskan pindah ke Mesir dan mulai dekat dengan Muhammad Abduh. Mereka bertemu pertama kali pada akhir tahun 1882 sewaktu Muhammad Abduh diusir dari Mesir dan datang ke Beirut. Dengan penuh keikhlasan Muhammad Abduh membina Ridha dalam pengembangan kepribadian dan keahliannya. Keakraban itu menimbulkan kecemburuan di kalangan murid-murid Abduh yang lain, khususnya yang berkebangsaan Mesir.

Sepeninggal Abduh, Rasyid Ridha melanjutkan apa yang telah dirintis bersama-sama gurunya, yakni pembaruan keagamaan, dengan meneruskan penerbitan majalah Al-Manar dan tafsir Alquran dengan nama yang sama. Sumbangan Rasyid Ridha pada pemikiran sistem politik lebih banyak dan lebih utuh meskipun bernapas tradisional dan kurang asli. Selain karena pembawaan

\footnotetext{
${ }^{35}$ Ibid., h. 125.

${ }^{36}$ Donohue dan Esposito (ed.), Islam dan Pembaharuan, h. 90.
} 
pribadi, pandangan politik Rasyid Ridha yang demikian tradisional itu tampaknya disebabkan oleh perkenalannya yang sangat terbatas dengan alam pikiran Barat yang antara lain disebabkan tidak dikuasainya bahasa-bahasa Eropa.

Corak pembaruan yang dibawa oleh Rasyid Ridha ini merupakan gerakan pembaruan yang sama sebagaimana yang dilakukan oleh Muhammad Abduh. Kemajuan Islam pada Zaman Klasik adalah karena mereka (umat Islam) mementingkan ilmu pengetahuan. Barat maju karena mereka berani mengambil ilmu pengetahuan yang dikembangkan oleh Islam. Jika umat Islam mengambil ilmu modern dari Barat, berarti usaha mengambil kembali milik Islam sendiri.

Setelah Muhammad Abduh wafat, Ridha aktif kembali dalam bidang politik. Ia menentang pemerintahan yang absolut, yakni Kerajaan Utsmani. Ia berusaha menjelaskan kepada dunia Islam, terutama dunia Arab akan bahaya politik kerjasama Arab dengan Negara Barat. Sebagaimana kebanyakan pemikir politik Islam Zaman Klasik dan Pertengahan, Rasyid Ridha tetap menganggap keturunan Quraisy sebagai salah satu syarat untuk dapat menduduki jabatan khalifah meskipun dalam hal ini ia mengikuti rasionalisasi Ibn Khaldun. Hal-hal yang dilakukan oleh Rasyid Ridha dalam mengadakan pemikiran pembaharuan diantaranya :

a. Untuk mengetahui Islam yang murni harus kembali kepada Alquran dan Sunnah.

b. Ajaran Islam katanya tidak membawa kepada statis tetapi dinamis.

c. Peradaban Barat tidak bertentangan dengan Islam, peradaban Barat sekarang berasal dari peradaban Islam zaman klasik.

d. Pembaharuan juga memasuki fiqh.

e. Rasyid Ridha menyalurkan pemikiran pembaharuannya melalui majalah yang diterbitkannya bernama al Manar. Majalah tersebut dibaca oleh mahasiswa yang datang dari berbagai pelosok dunia Islam yang studi di al-Azhar University, selesai studi mereka kembali ke tanah airnya membawa pemikiran pembaharuan yang disampaikan oleh Rasyid Ridha. Sehingga pemikiran pembaharuan tersebut menjalar ke berbagai penjuru dunia Islam.

Pada dasarnya pokok pikiran Rasyid Ridha tidak jauh berbeda dengan gurunya, terutama dalam titik tolak pembaharuannya yang berpangkal dari segi 
keagamaan, tuntutan adanya kemurnian ajaran Islam, baik dari segi akidahnya maupun dari segi amaliyahnya. Menurut pendapat dari Rasyid Ridha ummat Islam mundur karena tidak lagi menganut ajaran-ajaran Islam yang sebenarnya, dan perbuatan mereka telah menyeleweng dari ajaran-ajaran Islam yang sebenarnya. Di samping itu sebab-sebab yang membawa kemunduran ummat Islam, karena faham fatalisme, ajaran-ajaran tariqat atau tasawuf yang menyeleweng semua itu membawa kemunduran ummat Islam menjadi keterbelakangan dan menjadikan ummat tidak dinamis.

\section{Dampak yang Dihasilkan}

Beberapa dasawarsa setelah gerakan pembaharuan yang dilakukan oleh para reformis Mesir di atas, negeri ini dijadikan contoh yang paling menonjol mengenai dinamika keberagaman, hubungan antar agama dan masyarakat, tantangannya pada negara dan dampaknya pada proses demokratisasi. Mesir juga tempat lahirnya nasionalisme Arab dan kebangkitan Islam di bawah tiga pemimpin terakhir, yaitu Gammal Abdul Nasser (1918 - 1970 M), Anwar Sadat (1918 - 1981 M), dan Husni Mubarak (lahir 1928 M).

Dalam dekade selanjutnya gerakan dan pemikiran modernisasi Islam di Mesir menampakkan perkembangan yang pesat dengan munculnya berbagai gagasan dan gerakan yang berbeda dengan sebelumnya dalam berbagai bidang misalnya:

1. Bidang sosial politik dengan munculnya gagasan Trias Politika, patriotisme, emansipasi wanita, dan juga persatuan umat Islam seluruh dunia dalam rangka membendung pengaruh-pengaruh dunia Barat yang berusaha merongrong Islam dan kaum muslimin yang diwujudkan dengan berbagai gerakan sosial;

2. Bidang pendidikan dengan memunculkan gagasan bahwa semua bangsa Mesir harus mengenyam pendidikan secara merata, yang diupayakan lewat penataan kembali sistem pendidikan;

3. Bidang agama dan teologi dengan munculnya gagasan pemurnian ajaran Islam, menghilangkan kejumudan berpikir dan sikap fatalistik yang merupakan penyebab pokok kemunduran umat Islam; dan lain-lain, tokoh- 
tokoh yang sangat berpengaruh tidak hanya di Mesir, tetapi juga seluruh dunia khususnya Islam. ${ }^{37}$

M. Ridwan Lubis menyebutkan sejumlah dampak ekspedisi yang berkaitan erat dengan misi keilmuan dan kebudayaan yang dijalankan di Mesir adalah :

1. Timbulnya benih-benih rasa kebangsaan dari orang Mesir.

2. Negara Barat berusaha menggeser sistem pemerintahan yang dipraktikkan di Mesir yang sebelumnya berpola feodal menjadi lebih demokratis.

3. Sebagai hasil dari pendekatan Barat yang berpijak pada semangat revolusi Perancis maka muncullah pemikiran dari orang-orang Mesir yang mengusulkan agar bentuk pemerintahan yang diktator diubah menjadi pemerintahan demokratis, karena hal inilah yang membawa Perancis kepada suasana kehidupan kenegaraan yang baru.

4. Mulai terbukanya cakrawala berfikir dikalangan umat Islam sebagai akibat dari persentuhan dengan pemikiran para ilmuwan yang ikut dalam rombongan Napoleon. ${ }^{38}$

Sebagai akibat dari usaha pembaruan pendidikan Islam yang dilaksanakan untuk mengejar kekurangan dan ketertinggalan dari dunia Barat dalam segala aspek kehidupan, terdapat kecenderungan adanya dualisme dalam sistem pendidikan dunia Islam. Pola pembaruan pendidikan, membentuk suatu sistem atau pola pendidikan modern yang mengambil pola sistem pendidikan Barat, dengan penyesuaian dengan Islam dan kepentingan nasional serta tetap mempertahankan sistem pendidikan tradisional yang telah ada di kalangan umat Islam.

Sistem pendidikan modern pada umumnya dilaksanakan oleh pemerintah dalam rangka memenuhi tenaga ahli untuk kepentingan pemerintah, sedangkan sistem pendidikan tradisional yang ada di kalangan masyarakat tetap mempertahankan kurikulum tradisional yang hanya memberikan pendidikan dan pengajaran keagamaan. Dualisme sistem dan pola pendidikan inilah yang

\footnotetext{
${ }^{37}$ https://id.scribd.com/doc/47394724/Pembaharuan-Pendidikan-Islam-Di-Mesir, diakses pada tanggal 10 Januari 2018.

${ }^{38}$ M. Ridwan Lubis, Perspektif Pembaharuan Pemikiran Islam (Medan: Pustaka Widyasarana, 1994), hal. 32.
} 
mewarnai pendidikan Islam di semua negara dan masyarakat Islam pada zaman modern. Dengan adanya dualisme sistem pendidikan Islam, sistem pendidikan tradisional diharapkan akan berkembang secara berangsur-angsur mengarah ke sistem pendidikan modern. Inilah yang dikehendaki oleh para pembaharu pendidikan Islam yang berorientasi pada ajaran Islam yang murni. ${ }^{39}$

Jadi, upaya-upaya pembaruan yang dilakukan tesebut, telah memajukan pendidikan ummat Islam seperti kemajuan yang dicapai oleh bangsa-bangsa Barat.

\section{Penutup}

Berdasarkan uraian dan analisis sebagaimana yang disebutkan di atas dapat ditarik kesimpulan sebagai berikut; Pertama, latar belakang pendidikan Islam Mesir pada Abad ke-18 dipelopori oleh keberhasilan orang sipil Perancis membuka mata para pemikir Islam Mesir untuk melakukan perubahan, yaitu meninggalkan keterbelakangan menuju modernisasi di berbagai bidang, khususnya bidang pendidikan. Kedua dan Ketiga, strategi pembaruan pendidikan Islam dan aspek-aspeknya, ada banyak strategi yang dilakukan ketika itu; mulai dari mendirikan lembaga pendidikan sekolah, mengirim pelajar ke Barat, menciptakan inovasi baru dalam metode pendidikan, menata sistem dan struktur pendidikan, mengintegrasikan kurikulum pendidikan sampai kepada memperluas akses pendidikan. Keempat, tokoh-tokoh utamanya, diantaranya yang tersohor Muhammad Ali Pasya, Muhammad Abduh, dan Rasyid Ridha. Terakhir, dampak dari pembaharuan pendidikan Islam di Mesir pada saat itu terwujudnya kemajuan pendidikan ummat Islam seperti kemajuan yang dicapai oleh bangsa-bangsa Barat.

\footnotetext{
${ }^{39}$ Kodir, Sejarah Pendidikan Islam, h. 113.
} 


\section{Pustaka Acuan}

Donohue, John J. dan John L. Esposito (ed.) Islam dan Pembaharuan: Ensiklopedi Masalah-masalah. Terjemahan Machnun Husein. Jakarta: Rajawali Press, 1984.

Kodir, Abdul. Sejarah Pendidikan Islam dari Masa Rasulullah hingga Reformasi di Indonesia. Bandung: Pustaka Setia, 2015.

Putra Daulay, Haidar. Sejarah Pertumbuhan dan Pembaharuan Pendidikan Islam di Indonesia, Jakarta : Kencana, 2007.

Hamid, Abdul. Pemikiran Modern Dalam Islam. Bandung : Pustaka Setia, 2007.

Ihsan, Muhammad. Pendidikan Islam dan Modernitas di Timur Tengah: Studi Kasus Mesir. Jurnal Hunafa 4,2., 2007.

Journal.uinsgd.ac.id/index.php/jpi/article/download/549/pdf.

Lubis, Ridhwan. Perspektif Pembaharuan Pemikiran Islam. Medan : Pustaka Widyasarana, 1994.

Mukti, Abd. Pembaharuan Lembaga Pendidikan di Mesir. Bandung: Citapustaka Media Perintis, 2008.

Nasution, Harun. Islam Ditinjau dari Berbagai Aspeknya. Jilid ke- 2. Jakarta: UIPress, 1985.

Nasution, Harun. Pembaharuan dalam Islam, Jakarta: Bulan Bintang, 1983.

Nata, Abuddin. Sejarah Pendidikan Islam. Jakarta : Kencana Group, 2011.

Ramayulis. Dasar-dasar Pemikiran Pendidikan Islam. Jakarta : Media Pratama, 2001.

Rahman, Fazlul. Islam dan Modernitas tentang Transformasi Intellektual. Bandung: Pustaka, 1995.

Yatim, Badri. Sejarah Peradaban Islam. Jakarta : PT Raja Grafindo Persada, 2010.

Zuhairini. Sejarah Pendidikan Islam. Jakarta : Bumi Aksara, 2010. 